\title{
THE STATUTE OF THE CITY AND THE MASTER PLAN: INSTRUMENTS FOR SUSTAINABLE CITIES
}

Gabriela Soldano Garcezs

Lawyer and journalist. Master in Environmental Law and PhD student in International Environmental Law, both from Santos Catholic University.

gabrielasoldanogarcez@adv.oabsp.org.br

Mariana Vicente Braga Carmello

Santos Catholic University.

mariana-braga@uol.com.br

\begin{abstract}
The Master Plan is an important instrument to promote significant changes in Brazilian cities in order to achieve a sustainable development and create a new relationship between man and the environment. As far as this planning is concerned, the Master Plan is a basic tool to stablish guidelines to meet citizens necessities, as well as quality of life and social-economic development. For this purpose, citizens supervision and participation in local activities are necessary, so that Constitutional principles and democracy are accomplished. Civil society should be part of the decision-making process concerning enviromental public policies, as well as integrate elaboration, and supervision of these policies, taking into consideration that the public authorities, as well as the society, have to protect and defend the environment for the future generations (article 225, of the Federal Constitution). In this context, this task aims, firstly, evaluare the general guidelines od the Statute of the City (Law n ${ }^{\circ} 10.257 / 01$ ) and the importance of the Master Plans. Afterwards, adresses the participatory management as a way of implementing the sustainable cities.
\end{abstract}

Keywords: Statute of the City - Master Plan - Sustainable Cities Democratic Management. 


\section{INTRODUCTION}

The current national urban policy, formalized through the concepts brought by the Statute of the City and the Master Plans, has basal importance to the city plan, in order to build a healthy environment for the present and future generations.

The study of the cities Master Plans aims to organise the proper functioning of the city, combining socio-environmental role, well-being of the citizens and basic needs and, thus, the conduct of municipal public policies for the sustainable development.

Within this context, the present task addresses, first of all, the juridical foundation of the present urban development policy. Evaluates the guidelines of the Statute of the City (Law $n^{\circ} 10.257 / 01$ ), as well as analyses the city master plans.

Ultimalely, considers the democratic management of the city, emphasizing its importance to the edification of a sustainable city.

\section{URBAN LAW AND THE RELATIONSHIP BETWEEN CITY POLICY AND ENVIRONMENTAL PROTECTION}

Urban Law is the field in public law which comtemplates the rules and regulations of the urban activities.

Hely Lopes Meirelles warned that, concerning the urban law concept, all the areas where men have essencial role in the community are included. They are: housing, work, circulation and leisure (MEIRELLES, 2006, p. 513/514).

In constitutional matters, the urban law has arisen as an autonomous legal discipline only in the Federal Constitution of 1988, which, in the article 24, subsection I, sets the Union, the States and the Federal District the competence to legislate concurrently concerning the subject.

It is up to the Union, according to article $24, \S 1^{\text {o }}$, to establish the general rules; to the States, the supplementary federal and state legislation, as appropriate (article 30, subsection II).

Besides the article 24, subsection I, which refers exclusively to the legislative competence, the Constitution of 1988 comtemplates the urbanistic subject and others precepts, as, for example, in the article 21, subsections IX and XX, that sets to the Union the competence to elaborate and carry out the national and regional plans of territory ordination and social and economic development, and to the establishment of guidelines to the urban development, including housing, sewerage services and urban transportation.

As if this was not enough, the constituent dedicates an entire chapter to the Urban Policy under the title regarding the Financial and 
Economic Order.

In this regard, a warning should be given now - even in a superficial way, as this idea will be discussed later on - that the Constitution of 1988, when relating the general principles of the economic activity, refers clearly to the environment defense.

To José Afonso da Silva, the urban policy aims to build and order a balanced and healthy urban environment, where the qualities of a natural and artificial environment could coexist (SILVA, 2011, p. 1183).

On the other hand, Carlos Alberto Carmello Júnior and Gilberto Passos de Freitas remind us that the relationship between urbanistic activity and the use of spaces in intrinsic, perceiving this as the way to the rationalization of the use spaces, which is conditioned by the environmental preservation necessities (CARMELLO JUNIOR, 2012, p. 155).

Having clarified the concept of urban law and pointed the relationship between the urban policy and environmental protection, we can forward to the analyses of the coastal zone, its territorial occupation patterns and the main social-environmental consequences.

\section{Statute Of THE City: A GeNeral VIEW}

The Federal Constitution, in the chapter dedicated to the Urban Policy, establishes that the urban development policy, performed by the municipal Public Authorities, according to the general guidelines set out by law, aim to order the full development of the city social activities, as well as ensure the well being of the inhabitants (article 182, caput).

The diploma which refers to the constitutional text is the Law $10.257 / 2001$ (Statute of the City).

Though the Statute of the City does not comtemplate neither the concept defining rules nor the imposing specific obligations for the environment custody, unlike what it does to the ownership and use of the soil, its contribution to the environmental protection is expressed.

\subsection{Social Role of the Urban Property}

According to the article $2^{\text {nd }}$, caput, of the Statute of the City, the urban policy aims to order the full development of the social roles of the city and the urban property.

As it is musty, the constitutional order unites indissolubly the social role and the property right.

Yet there are still those who, nevertheless, intend to evade the environmental laws and regulations under the protection of the individual property rights (MARCHESAN, 2011, p. 340).

Also, there are those who mistakenly claim that the environmental protection represents an intervention to the private property rights. 
Antônio Herman de Vasconcellos e Benjamin warns that the environmental protection takes part in the genesis of the property rights, as we can say the Environmental Law is due to the Property Law and the Public Law. It has taught that, in the light of the Federal Constitution of 1988, the established relationship does not represent intervention because the constituent has not conceived first the right to property to recognise the necessity for the environmental guardianship, marking that this is logically previous to that once the right to property does not exist without environmental safeguard, and historically contemporary, as both are recognised at the same moment in an unique normative text. (BENJAMIN, 2011, p. 7/8).

In the present constitutional order, without environmental safeguard, the property right - in its fullness - is not acknoledged. Therefore, there is no intervention, which presupposes the act from inside out, but interference. And, under the Federal Constitution of 1988, this interference is imposed both to the Public Authorities and to the private and it is the fundament of the non-obviation of the environmental obligations.

The apparent inexhaustibility of the natural resources, together with factors from different orders, has led, in the past, to the untrue conception of the predatory exploration of the land and its attributes. More recently, the Constitutions started to contemplate the protection of the environment as presupposed recognition of a valid property right.

It is certain that, from the constitutional foreknowledge of the property right, derive the power of claiming, usage, enjoyment, disposal and transfer. The constitutional text is limited to consagrate the institute, which has its content defined by the infra-constitutional legislation.

The legal literature says that the property experiments both internal and external limits. The first ones are intrinsic and contemporary to the controlling relationship while the last ones are consecutive. Those, as a rule, have the same origin: the social function of the property.

It must not be forgotten that the social function of the property reveals itself not only through negative impositions, but mainly through positive benefits. Concerning the environmental protection, the constituent, article 225, caput, from the Constitution, has imposed to the Public Authority and to the community, the duty to defend and preserve it to the present and future generations.

As if that were not enough, the article 170 of the Constitution, when relating the general principles of the economic activity, contemplates not only the social function of the property, but also the environmental defense.

In relation to the urban property, the article $182, \S 2^{\circ}$, of the Federal Constitution constrains the fullfilment of the social function to the meeting of fundamental requirements of the city ordination 
expressed in the Master Plan.

\subsection{Sustainable Cities}

The assurance of the right to the sustainable cities is the first general guideline related in the article $2^{\text {nd }}$ of the Statute of the City.

The legislator has proceeded, defining the right to sustainable cities as the right to urban land, to housing, to environmental sanitation, to urban infrastructure, to transportation and public services, to work and leisure, to the present and future generations.

We can thus conclude that urban sustainability is not restricted to the environment, covering the expression of economic, social, cultural and political factors.

Maria Luiza Machado Granziera warns that the matter of sustainability rests on the tripod of economy, society and environment, leaving to the Public Authorities the obligation to provide the balance between these elements, conciliating the economic development with the environment protection (GRANZIERA, 2011, p. 1245).

It must not be forgotten that the guidelines presented by the article $2^{\text {nd }}$ find resonance in the instruments provided by article $4^{\text {th }}$ (which will be analysed in the lines ahead) or, in other words, the instruments serve the implementation of the guidelines, and, consequently, the attainment of the urban policy objective, which, according to the legislator, is to order the full development of the social functions of the city and the urban property.

If so, the subsections I, II and III of the article $4^{\text {th }}$, which provide, respectively, the use of nacional, regional and state plans of territory order and economical and social development; of municipal planning, related to the guideline provided by article $2^{\text {nd }}$, subsection I (right to sustainable cities), through which, the urban policy objective is accomplished.

The intrinsic relationship which is established among instruments, guidelines, objectives and guiding constitutional principles of the economic activity allows the interpreter to come to the conclusion that the implementation of the Statute of the City has defense of the environment as a logical and necessary presupposition.

At last, yet referring to the right to sustainable cities, it is important to register that the legislation has expressly mentioned the intergenerational justice, which aims to guarantee that the future generations can enjoy present resources (SILVA, 2008, p. 77). 
4. URBAN AND HOUSING POLICY INSTRUMENTS UNDER THE LIGHT OF THE ENVIRONMENTAL POLICY

The urban development policy aims to order the social environmental functions of the city, ensuring the inhabitants well-being, facing the guidelines established in the article $2^{\text {nd }}$ of the Statute of the City.

Several are the current instruments of the urban and housing policy, according to the article $4^{\text {th }}$, Law $\mathrm{n}^{\mathrm{o}} 10.257$, of 2001 , which regulates the articles 182 and 183 of the Federal Constitution of 1988.

Article $4^{\text {th }}-$ For the purposes of this law, will be used among other instruments:

I - nacional, regional and state plan of territory order and economic and social development;

II - metropolitan regions, urban agglomerations and microregions planning;

III- municipal planning, mainly:

a) master plan;

b) discipline of the land subdivision, land use and land cover;

c) environmental zoning;

d) multi-annual plan;

e) budget guidelines and annual budget;

f) participatory management of the budget;

g) sector plans, programs and projects;

h) economic and social development plans;

$I V-$ tax law and financial institutes:

a) urban real estate property tax - IPTU;

b) improvement contribution; 
c) tax incentives and financial benefits;

$V-l a w$ and policy institutes:

a) expropriation;

b) administrative servitude;

c) administrative limitations;

d) real estate protection;

e) foundation of conservation units;

f) foundation of special zones of social interest;

g) grant to real right of use;

h) grant for special use for housing purposes;

i) compulsory fragmentation, building and use;

j) special adverse of urban properties;

l) leasehold land rights;

m) preemptive rights;

n) right to grant costly build and change in use;

o) transfer of the right to build;

p) urban operations in consortium;

q) landholding regularization;

r) free legal and technical assistence to underprivileged communities and social groups;

s) referendum and plebiscite;

t) urbanistic demarcation for land regularization;

u) ownership legitimation. 
VI - Previous study of the environmental impact (EIA) and previous study of neighborhood impact $(E I V)$.

To implement the right to housing, urban services, sewage disposal, health, education, leisure, balanced environment for all the citizens, as well as other rights concerning life, the instruments mentioned above are indispensable.

However, the city has, as the main urban policy instument, the Master Plan, once there is, for the effectiveness of the instruments mentioned in the Statute of the City, the necessity of its inclusion in the municipal Master Plans, besides specific municipal laws aiming implementation and application.

\subsection{The importance of the Master Plan in the building of a sustainable city}

According to the Federal Constitution of 1988, the cities with over 20.000 inhabitants must adopt, mandatorily, a Master Plan as a basic instrument of the development policy and urban expansion (article 182, paragraph $1^{\text {st }}$ ). Besides that, for the cities with over 500.000 inhabitants, there is the need for a plan of integrate urban transport, which should be compatible with the Master Plan previously adopted.

The Master Plan should include the fundamental criteria and demands to order the city, aiming to meet the socio-environmental function of property, which has to be defined in the Master Plan.

This way, if the Statute of the City establishes the general guidelines of the urban policy, the Master Plan establishes the specific guidelines, directed to the meeting of the real situation and the local needs.

After being approved by law, the Master Plan becomes part of the municipal planning, focusing on the multi-annual plan, on the budget guidelines and on the municipal annual budget.

The fundamental principles, guided by the master plan, reflect the constitutional principles of the urban policy stipulated in the fundamental principles of the Democratic State of Law, of citizenship and humam dignity, in the principles of popular sovereignty (direct democracy-popular participation), equality, aimed at the protection and exercise of the right to the city and also guarantee 
a healthy and ecologicaly balanced environment (SAULE JUNIOR, 1999, p. 117).

On account of being a complex instrument, a multidisciplinary team is needed for its preparation.

To Adilson Abreu Dallari, the Master Plan is a condition to implement several other urban policy instuments (DALLARI, 2006, p. 334).

With explicit strength, it is from the Plan that all the public and private actions to solve city problems will come, in order to achieve "the ideal city of the future" (SOARES, 2001, p. 54).

It is, therefore, a municipal planning that aims the socioeconomical development of the city, as well as the environmental balance, in a way that all the inhabitants can have worthy and healthy life conditions.

To the elaboration of the Master Plan, the participation of the population and social representative associations should be guaranteed, besides the publishing of all the produced information, according to the paragraph $4^{\circ}$, article 40 , Statute of the City.

Afterwards, a draft law to be approved will be elaborated by the Executive Power, through the City Council, according to the legislative process created by the Organic Law of the City.

The law which creates the Master Plan should be revised each 10 years (paragraph $3^{\circ}$, article 40 , Statute of the City).

Concerning the way of changing the master plan, the review of this instrument derives from the need to adapt the public policies to the new necessities of the society, which is in constant change, and also, to evaluate the level of effectiveness achieved, in order to promote a better result from that date on. This demand for periodic review has become a legal obligation (SOARES, 2001, p. 56).

Even during the review period, the Master Plan should meet mandatorily the socio environmental principle of the city, in order to guarantee the right to a sustainable city, adopting measures to ensure the right of the citizens, the ecologically balanced environment, the incentive to the economic activities, quality of life, among other items which are indispensable to the city.

The right to the city comprises the inherent right of the people who live in the cities to have the conditions of a life of dignity, to fully exercise the citizenship, to create, to extend the fundamental 
rights (individual, economical, social, political and environmental), to take part in the city management, to live in an ecologically balanced, healthty and sustainable environment (SAULE JUNIOR, 1999, p. 118).

Within this context, the Coastal Zone cities should offer special attention to the urban planning of this area through the Master Plan.

\section{PARTICIPATORY CITIZENSHIP: THE DEMOCRATIC MANAGEMENT OF THE SUSTAINABLE CITY}

The caput, from article 225, of the Constitution, imposes both to the Public Authorities and to the society the obligation to defend and preserve the environment.

According to the constitutional rule of the caput of the article 225, the environmental defense by the civil society is not only composed by mere voluntarism and altruism of a few idealists, but is formed by the fundamental legal obligations, revealing the double nature of right and fundamental obligation of the constitutional approach conferred to the environmental protetcion (FENSTERSEIFER, 2008, p. 123).

The society takes part in the environmental management preserving the environment, as it respects the established rules about the subject, as well as demanding actions or policies from the Public Authorities regarding environmental protection, as the formulation of new protection rules, or, still, the effective proceeding of supervisory authorities, in order to condition and orient the political actions of the public interests.

In this way, the citizens are legitimated to supervise and delate the acts of the government, as well as protect their own rights and those of the collective custody. Ultimately, the citizen should take part directly and actively in the decision-making processes in which their interests are involved.

The society has, therefore, the duty to act in defense of the environment, baring in mind that the social participation is the "instrument truly able to boost the full respect of the environmental law, to transform the quality of life of the population and to preserve the environment for the present and future generations" (ARRUDA, 1997, p. 239).

The principle of participation composes one of the fundamental postulates of the Environmental Law. 
Although still incipient in our country, the truth is that this postulate is currently one of the main weapon, if not the most efficient and promising, in the fight for a more ecologically balanced environment (RODRIGUES, 2002, p. 255/256).

Without the participation of the citizens, the concretion of the environmental democracy becomes impossible.

Concerning the environmental issues, the participation should be present, baring in mind the possible repercussion of the collective environmental degradation, as well as the nature of the diffuse transindividual rights (and, therefore, naturally collective), which imposes a democratic process and transparent decision-making about these issues.

In the light of the organizational perspective, the responsability lies with the State to create institutions and suitable procedures which make the popular participation possible, motivating the intervention and popular control of the decision-making involving environmental issues.

In relation to the city planning, the popular participation has gained attention in the Statute of the City, which has tried to join public authorities and society together.

The great advance of the law $n^{\circ} 10.257 / 01$ - Statute of the City, was in order to count on the participation of the society in a public planning process, providing a series of instruments to induct the development of sustainable cities, such as: the finance of the urban policy, democratization of the urban management, as well as the ownership regularization (SOARES, 2001, p. 43).

The Statute imposes the social control over the urban policy as it positions the democratic management among its principles (article $2^{\circ}$, subsection II).

There is, still, express provision that all the instruments prospected in the article $4^{\circ}$, which demand resources from the municipal Public Authorities (such as: master plan, multi-annual plan, previous studies on the environmental impact, among others) should be subject of control guaranteed to the participation of the communities, motion and civil society entities (paragraph $3^{\text {rd }}$, article $4^{\circ}$ ).

"The inhabitants of the city and the territories should act in favor of a unique urban space, cohabitaded by millions of individuals who share the same urban and institutional infrastructure" (SOARES, 2001, p. 49).

The Statute of the City determines, yet, that the Master Plan 
should count on the participation of the population in its elaboration and supervision process, and also the community associations, through the acess to information, publishing, as well as public audiences and consulting (article 40, paragraph $4^{\text {th }}$ ).

The master plan as an instrument of participatory planning, to guarantee the right of the community to participate in all the phases of the process, should contain democratic mechanisms which allow the practice of the active citizenship, involving mechanisms related to the elaboration phase, such as the right to obtain information, to present propositions to amendments; public hearings and referendum, as well as its implementation phase and review through the democratic planning system (SAULE JUNIOR, 1999, p. 118).

The democratic management of the city is guaranteed through the collegiate organs of urban policy, in the national, state and municipal levels; debates, hearings and public consultation; conferences about urban interests, in the national, state and municipal levels; and/or, still, popular initiative concerning draft law and plans, programs and urban development projects (article 43).

Besides, the managing bodies of the metropolitan regions and urban aglomerations will include mandatory and significant participation of the population and representative associations of various segments of community in order to guarantee the direct control of its activities and full exercise of citizenship (article 45).

Thus, concerning the planning of the metropolitan plans, they should be elaborated together, taking on account the interaction between the cities, taking on account that the decisions generate repercussion in everyone, for it is a urban aglomeration, the potencial problems (involving environmental issues or not) are usually the same, and therefore, should be analysed, looking for sollutions in a group, to benefit all the cities involved.

The paragraph $3^{\text {rd }}$ of the article 25 of the Federal Constitution/88, establishes that from the common interest metropolitan regions (urban aglomerations and microregions) could be created through the complementary state law. This group of cities aims to integrate the organization, the planning and execution of public functions of common interest, indicating, therefore, ways to new configurations of 
the territory and its administration in the perspective to reach the sustainable development through the search of an adequate territory to the managing of ordinary problems. It is all about motivating the inter-municipal solidarity (SILVA, 2006, p. 14/15).

We come to the conclusion that the legislation imposes the participation of everyone. The citizens are invited to exercise their civil duties, through participatory citizenship, aiming to solve the problems of the community, by the co-management of the urbanistic plans.

The right to the sustainable city will only be feasible when the population gets involved in the decision-making processes of the environmental urban conflicts, aiming the sustainable development of the city, as well as, concerning the urban planning, making it possible and encouraging the popular participation.

The democratic management of the city is imperative to the suitable urban planning.

\section{Conclusion}

The balanced and healthy urban environment presupposes the coexistence of the quality of a natural environment and the quality of an artificial environment. It is certain that the care with first one has direct repercussion in the protection of the second one to the extent that natural environment suffers the consequence of urban environmental degradation.

The Federal Constitution of 1988, in the chapter dedicated to the Urban Policy, establishes that the urban development policy, whose execution competes to the municipal Public Authority, according to the general guidelines set out by law, aims to order the full development of the social functions of the city and to guarantee the well-being of its inhabitants (article 182, caput).

The diploma referred to in the constitutional text in the Law $10.257 / 2001$ (Statute of the City), which, in the article $2^{\text {nd }}$ of the Statute of the City, relates the urban policy guidelines, assigning to the City a special role in the environmental protection.

The guidelines presented by the article $2^{\text {nd }}$ find resonance in the instruments provided by the article $4^{\text {th }}$. This latter, in the subsection III, paragraph A, the Master Plan foresees that, in the diction of the article 40 , is the basic instrument of the development and urban expansion policy.

The Master Plan is, therefore, in a last analyses, the most relevant instrument to make the urban policy concrete. It is from its concepts that the social function of urban property is fullfilled. 
The Statute of the City, besides listing instruments of discipline of the use of the land, provides instruments which make the direct democracy concrete, and was chosen by the constituent in the article $1^{\text {st }}$, sole paragraph, of the Federal Constitution of 1988. To the list of instruments contained in the constitutional text (plebiscite, referendum and popular initiative), the Statute of the City has added other ones, in a list merely provided as an example (article 43).

We can not forget that the conscientious and vigilant participation of the inhabitants, something which is not part of the Brazilian citizenship habits yet, will build sustainable cities.

\section{REFERENCES}

BENJAMIN, Antonio Herman. Reflexões sobre a hipertrofia do direito de propriedade na tutela da reserva legal e das áreas de preservação permanente. Disponível em: <http://www.egov.ufsc.br/ portal/conteudo/reflex\%C3\%B5es-sobre-hipertrofia-do-direito-depropriedade-na-tutela-da-reserva-legal-e-das- $\% \mathrm{C} 3 \% \mathrm{~A} 1 \mathrm{rea}>$. Acesso em: 06 de setembro de 2014.

CARMELLO JÚNIOR, Carlos Alberto; FREITAS, Gilberto Passos de. A cidade sustentável e o Direito Penal Ambiental. In: LECEY, Eladio e CAPPELLI, Sílvia (Coord.). Revista de Direito Ambiental, v.17, n.68, p. 153-178. São Paulo, out/dez 2012.

DALLARI, Adilson Abreu; FERRAZ, Sérgio. Estatuto da Cidade Comentários à Lei Federal $\mathbf{n}^{\mathbf{0}} \mathbf{1 0 . 2 5 7 / 1 0}$. 2.ed. São Paulo: Malheiros, 2006.

FENSTERSEIFER, Tiago. Direito fundamentais e proteção do ambiente: a dimensão ecológica da dignidade humana no marco jurídico-constitucional do Estado Socioambiental de Direito. Porto Alegre: Livraria do Advogado Editora, 2008.

FIORILlO, Celso Antonio Pacheco. Curso de direito ambiental brasileiro. 10. ed. São Paulo: Saraiva, 2009.

GRANZIERA, Maria Luiza Machado. Direito Ambiental. 2.ed. São Paulo: Atlas, 2011.

Meio ambiente urbano e sustentabilidade. In: MILARE, Edis e MACHADO, Paulo Affonso Leme (Org.). Direito Ambiental: meio ambiente urbano. São Paulo: Editora Revista dos Tribunais, 2011.

KRELL, Andreas J. A falta de sustentabilidade jurídico-ambiental da ocupação do litoral brasileiro pela construção civil. In: DAIBERT, Arlindo (Org.). Direito ambiental comparado. Belo Horizonte: Fórum, 2008. 
MARCHESAN, Ana Maria Moreira. Preservação ambiental e ocupação do espaço urbano à luz do Estatuto da Cidade (Lei 10.257/2001). In: MILARÉ, Édis e MACHADO, Paulo Affonso Leme (Org.). Direito Ambiental: meio ambiente urbano. São Paulo: Editora Revista dos Tribunais, 2011.

MARTINS JÚNIOR, Wallace Paiva. Participação Popular no Estatuto das Cidades. In: FINK, Daniel Roberto (Coord.). Temas de Direito Urbanístico. São Paulo: Imprensa Oficial do Estado, 2005.

MEIRELLES, Hely Lopes. Direito Municipal Brasileiro. 15 ed. São Paulo: Malheiros, 2006.

MILARÉ, Édis; BENJAMIN, Antonio Herman. Estudo Prévio de Impacto Ambiental: teoria, prática e legislação. São Paulo: Editora Revista dos Tribunais, 1993.

RODRIGUES, Marcelo Abelha. Instituições de Direito Ambiental. Volume 1 - Parte Geral. São Paulo: Max Limonad, 2002.

SALEME, Edson Ricardo. Parâmetros sobre a função social da cidade. Disponível em: <http://www.conpedi.org.br/manaus/arquivos/ anais/XIVCongresso/141.pdf $>$. Acesso em: 06 de setembro de 2014.

SANTIN, Janaína Rigo; MATTIA, Ricardo Quinto. Direito Urbanístico e Estatuto das Cidades. In: MILARÉ, Edis e MACHADO, Paulo Affonso Leme (Org.). Direito Ambiental: meio ambiente urbano. São Paulo: Editora Revista dos Tribunais, 2011

SAULE JUNIOR, Nelson. Direito à cidade - trilhas legais para o direito às cidades sustentáveis. São Paulo: Max Limonad, 1999.

SILVA, Carlos Henrique Dantas da. Plano Diretor: Teoria e Prática. São Paulo: Saraiva, 2008.

SILVA, Solange Teles da. Planejamento urbano na Zona Costeira. In: Anais do XIV Congresso Nacional do Conselho Nacional de Pesquisa e Pós-Graduação do Direito - Conpedi, de Fortaleza/2005. Florianópolis: Fundação Boiteux, 2006. Disponível em: <http://www. conpedi.org.br/manaus/arquivos/anais/XIVCongresso/151.pdf > . Acesso em: 01 de setembro de 2014.

SILVA, José Afonso da. Direito Urbanístico Brasileiro. 2 ed. São Paulo: Malheiros, 1997.

SILVA, José Afonso da. Direito Urbanístico e Meio Ambiente. In: MILARÉ, Édis e MACHADO, Paulo Affonso Leme (Org.). Direito Ambiental: meio ambiente urbano. São Paulo: Editora Revista dos Tribunais, 2011

SOARES, Cynthia Martins. A cidadania participativa e o Plano 
Instruments for Sustainable Cities - Soldano Garcezs and Braga Carmello

Diretor. In: O Direito Ambiental: desafios e soluções. CONCEIÇÃO, Maria Collares Felipe da (org.). Rio de Janeiro: Móbile, 2001. 